Indexed by

\section{Scopus}

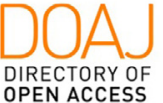

OPEN ACCESS

JOURNALS

Crossref

$\mathrm{R} \odot \mathrm{AD}$

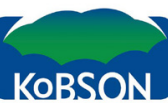

Foogle

\title{
A SURVEY ON THE SAFETY SYSTEM MATURITY LEVELS OF ELECTRONICS MANUFACTURERS IN SOUTH KOREA
}

\section{Joo Yong Shim}

Seoul National University of Science And Technology, Department of Safety Engineering, Seoul, South Korea

\section{Dal Jae Park}

Seoul National University Of Science And Technology, Department of Safety Engineering, Seoul, South Korea

\section{Jeong Hwa Park}

Seoul National University Of Science And Technology, Department of Safety Engineering, Seoul, South Korea

\author{
Jung Mo Lee \\ ChonnNam National Universi- \\ ty, Mechanical Design Engi- \\ neering, Seoul, South Korea
}

\author{
Jae-Yong Lim \\ Seoul National University Of \\ Science And Technology, De- \\ partment of Safety Engineer- \\ ing, Seoul, South Korea
}

Key words: electronic manufacturing enterprise, smart factory, safety system assessment checklist, safety system maturity

doi:10.5937/jaes0-30973

\section{Cite article:}

Shim, J. Y., Park, J. H., Lee, J. M., Park, D. J, Lim, J-Y. (2021) A SURVEY ON THE SAFETY SYSTEM MATURITY LEVELS OF ELECTRONICS MANUFACTURERS IN SOUTH KOREA, Journal of Applied Engineering Science, 19(3), 642-648, DOI:10.5937/jaes0-30973 


\title{
A SURVEY ON THE SAFETY SYSTEM MATURITY LEVELS OF ELECTRONICS MANUFACTURERS IN SOUTH KOREA
}

\author{
Joo Yong Shim ${ }^{*}$, Jeong Hwa Park', Jung Mo Lee², Dal Jae Park', Jae-Yong Lim \\ ${ }^{1}$ Seoul National University Of Science And Technology, Department of Safety Engineering, Seoul, South \\ Korea \\ ${ }^{2}$ ChonnNam National University, Mechanical Design Engineering, Seoul, South Korea
}

The main objective is to identify the level of advancement of safety systems in various levels of smart factories. Smart level verification systems are being implemented in Korea, but safety systems are not paying much attention to smart factory level checks. Using a checklist, nine Korean electronics manufacturing enterprises checked their level of safety system. The checklist consists of 142 items, which were divided into four dimensions (laws and certifications, safety designs and configurations at the facilities, safety devices and guards, and maintenance and training). As a result, a high-ranked enterprise in smart factory level showed excellence in the safety system maturity level as well. Compared to the level of the company's smart factory, the level of advancement of safety systems has been confirmed to be lower.

Key words: electronic manufacturing enterprise, smart factory, safety system assessment checklist, safety system maturity

\section{INTRODUCTION}

Globally, more than two thirds of enterprises either operate smart factories at present or plan to construct a smart factory [1]. This is because intelligent manufacturing systems such as Smart Factory generate a lot of profits (increase productivity, reduce costs, etc) for companies [2]. In addition, a plan was announced in South Korea to institute a "Public-Private Joint Smart Factory Promotion Team" and build about 30,000 smart factories, merging ICT (Information communication technology) with the manufacturing and production processes of Small and Medium-sized Enterprise by 2025 [3]. Various maturity models have been developed to systematically evaluate the state of the company in its transition to smart factory. A maturity model is a tool for conceptualizing and measuring the maturity of an organization or process with respect to a particular target state [4]. The maturity assessment aims to identify the current state in the process of reaching the target stage of the entity. There are models to evaluate readiness or maturity associated with Industry 4.0.

In Germany, the "Readiness Model" (RM) evaluates the Industry 4.0 maturity of enterprises in six dimensions, one of which is titled, "smart factory" [5]. The RM helps identify the level of smart factory maturity, however it is not suitable for assessing the advanced safety system of enterprises because safety is not a primary concern with the RM. In addition, there are various models [4, $6,7,8]$, but there are no detailed items about the safety system. It is necessary to include safety systems in the maturity assessment. This is because if industrial 4.0 related technologies are used for safety, this will lead to improvement of process safety [9]. Furthermore, smart factory is characterized by new types of processes, technologies, or organizational change. Such system changes bring about new and emerging risk factors, and it is essential to identify and prevent these risks [10, 11]. Also, system changes affect other subsystems and processes. It means that advanced safety system should not be carried out separately because it interacts with other systems [9]. Besides, the transition to smart factory may require different strategies depending on the size of the enterprise. Some studies [3,12] show that safety management of different approaches is needed depending on the size of the enterprise.

In South Korea, the "Smart Factory Level Verification System" (SFLVS) has been in effect since 2019 [13]. The system classifies the level of an enterprise's smart factories with 44 items, but there are only two items regarding safety. Obviously, it is insufficient to evaluate the advanced safety system.

In addition, other studies [14-16] concerning smart factory risk management, do not provide safety system details sufficiently. As mentioned above, the current models were to examine, with minimal attention paid to the safety system, the different levels of smart factory.

The present study aims to check the advanced safety system in smart factories through a checklist and to identify that the same level of safety systems are established. As the first step, advanced safety system was defined based on smart factory evaluation models. Afterwards, the checklist was made based on laws and standards related to prior research and existing smart factories. Finally, the checklist was applied to nine electronic manufacturing workplaces to evaluate and compare their smart factory level and degree of advanced safety system. 
Table 1: Comparison definitions of safety system maturity and smart factory level verification system

\begin{tabular}{|c|c|c|}
\hline & Checklist (Safety 'n') & $\begin{array}{c}\text { Smart Factory Level Verification System } \\
\text { (Levels) [17] }\end{array}$ \\
\hline Safety IV (Level 4-5) & $\begin{array}{c}\text { Component failures, exchange cycle prediction } \\
\text { and proactive protection measures through big } \\
\text { data and Al technology, autonomous safety } \\
\text { checks of CPS (self-compatibility declaration) }\end{array}$ & $\begin{array}{c}\text { Autonomous operation from monitoring } \\
\text { to control to optimization (Level 5) } \\
\text { Simulate to optimize proactive response } \\
\text { and decision making (Level 4) }\end{array}$ \\
\hline Safety III (Level 3) & $\begin{array}{c}\text { Facility/automatic control through abnormal } \\
\text { condition monitoring, history management, and } \\
\text { facility life predictions }\end{array}$ & $\begin{array}{c}\text { Analyze and control the collected infor- } \\
\text { mation (Level 3) }\end{array}$ \\
\hline Safety II (Level 2) & $\begin{array}{c}\text { Monitoring the safety of machinery and equip- } \\
\text { ment (including module facilities) and workers }\end{array}$ & $\begin{array}{c}\text { Enables real-time monitoring of produc- } \\
\text { tion information (Level 2) }\end{array}$ \\
\hline Safety I (Level 0-1) & $\begin{array}{c}\text { Safety standards for machinery and equipment } \\
\text { (including module facilities) in both domestic } \\
\text { and foreign cases }\end{array}$ & $\begin{array}{c}\text { Partial standardization and performance } \\
\text { information management (Level 1) } \\
\text { Unrecognized and ICT not applied }\end{array}$ \\
\hline
\end{tabular}

\section{METHODS}

\section{Safety system maturity levels}

In this study, the word "safety system maturity" is used to describe the "advanced safety system". Previous models such as RM, SFLVS, are not suitable for the assessment of safety system maturity levels because their primary concern is to measure smart factory maturity, not safety. To check on safety system maturity, four levels were considered in this study. Table 1 shows the safety systems maturity levels in this study.

Safety I (=basic), the lowest level of safety system maturity, refers to the absence of ICT or compliance with safety standards. Note the three representative models above. They have a common feature of ICT; 1) the RM classifies six stages based on the three criteria (the degree of information technology, strategy, investment in Industry 4.0), 2) RAMI 4.0 indicates the importance of information exchanges and decision-making between layered production system structures [18], 3) SFLVS classifies enterprises with respect to ICT utilization in such a way that non-ICT applied enterprises are assigned into the lowest stages.

The Safety II to IV ranges are based on the SFLVS in Korea. Safety II (=intermediate 1 ) is associated with simple monitoring and data collection, and Safety III (= intermediate 2) with control and data analysis through monitoring. Safety IV (=advanced) includes proactive responses through simulations, real-time safety control through Al, capability of component life predictions using big data, and the autonomous safety verification of module facilities using cyber-physical systems.

In addition to ICT, continuous modularization and flexibility in manufacturing process is one of the key concepts of Industry 4.0. During modular facilities installations, problems are often observed at the interfaces between different modules [19]. Therefore, it is necessary to consider possible risk factors such as "facility modularization" or "module facility coupling." To ensure the safety of flexible production systems is also one of key parts in the safety system.

\section{Procedure for proposing the checklist}

The procedure for the checklist construction is as follows. First, the checklist presented in earlier research [20], was reviewed and rearranged. It was then verified by experts working in the areas of IT and industrial machinery (e.g., automated guided vehicles, safety sensors, and circuits) for any missing items. Second, safety standards applied to key devices among smart factory construction facilities were reviewed. Those are on industrial robots, cooperative robots, conveyors, and automated guided vehicles. Then, the above items related to the safety system maturity were added to the checklist. Third, maintenance of facilities and safety education items were inserted to the checklist. Despite the significance of the safety management aspects, those were not contained in the previous study [20]. Relevant items were extracted from the KOSHA Guide [21]. Fourth, the checklist was finally reclassified as "Items via interviews and document verification" and "Items for on-site facility installation and status" for convenience of workplace survey. Finally, the final checklist consists of 142 items.

\section{Checklist configuration}

The dimensions and details of the safety system maturity level assessment checklist are shown in Table 2. The 142 items in the checklist are largely divided into four dimensions: 1) laws and certifications, 2) safety designs and configurations at the facilities, 3) safety devices and guards, and 4) maintenance and training. Again, the four dimensions can be subdivided into 21 subcategories. All the items belong to one of the four levels designated by Safety I, Safety II, Safety III and Safety IV, and each level has $90,17,20$ and 15 items, respectively. From now on, we will refer to the four levels as "Safety n." 
Table 2: Categories and detailed items of the safety system evaluation checklist

\begin{tabular}{|c|c|c|}
\hline Dimension & Detailed item & References \\
\hline \multirow{2}{*}{ Laws and certifications } & Mechanical equipment & \multirow{8}{*}{$\begin{array}{c}\text { Occupational Safety and Health Act } \\
\text { Article } 34 \text { (Safety Certification), Ar- } \\
\text { ticle } 34-2 \text { (Indication, etc. of Safety } \\
\text { Certification), Article } 35 \text { (Reporting } \\
\text { on Voluntary Safety Verification), } \\
\text { Article } 35-2 \text { (Indication, etc. of } \\
\text { Voluntary Safety Verification), Article } \\
36 \text { (Safety Inspections), Article 36-2 } \\
\text { (Safety Inspections under Self-In- } \\
\text { spection Program) }\end{array}$} \\
\hline & Safety Control System & \\
\hline \multirow{5}{*}{$\begin{array}{c}\text { Safety designs and configurations at } \\
\text { the facilities }\end{array}$} & $\begin{array}{l}\text { Information Operations Technology } \\
\text { and Communications Network }\end{array}$ & \\
\hline & Cooperative work safety & \\
\hline & Modular Equipment & \\
\hline & Control device (portable) & \\
\hline & Safety guard & \\
\hline \multirow[b]{2}{*}{ Safety devices and guards } & Safety device (sensor) & \\
\hline & $\begin{array}{l}\text { Compliance with working regula- } \\
\text { tions }\end{array}$ & \multirow{4}{*}{$\begin{array}{l}\text { Enforcement Decree of The Occu- } \\
\text { pational Safety and Health Act } \\
\text { Article 28-5 (Machinery, Tools, etc., } \\
\text { subject to Voluntary Safety Con- } \\
\text { firmation), Article 28-6 (Harmful or } \\
\text { Dangerous Machinery Subject to a } \\
\text { Safety Inspection) }\end{array}$} \\
\hline \multirow{10}{*}{ Maintenance and Training } & No-manipulation indication & \\
\hline & Safety monitoring & \\
\hline & Energy release & \\
\hline & Operation documents in the right & \multirow{7}{*}{$\begin{array}{l}\text { Enforcement Rules of the Occupa- } \\
\text { tional Safety and Health Act } \\
\text { Article } 124 \text { (Application for Safety } \\
\text { Inspection), Article } 126 \text { (Period of } \\
\text { safety inspection and the method of } \\
\text { acceptance and indication) } \\
\text { Notice on the procedure of safety } \\
\text { certification and autonomous safety } \\
\text { confirmation reports } \\
\text { Safety Inspection Notice } \\
\text { ISO 10218-1, ISO 10218-2, ISO TS } \\
\text { 15066, ISO 13849-1 } \\
\text { IEC 61508, IEC 60204 } \\
\text { DIN EN 1525 } \\
\text { DGUV 209-074 Industrieroboter } \\
\text { Technical Standard for Driverless } \\
\text { Industrial Trucks (S3-M-13) }\end{array}$} \\
\hline & & \\
\hline & $\begin{array}{l}\text { Establishing maintenance regula- } \\
\text { tions }\end{array}$ & \\
\hline & $\begin{array}{c}\text { Operation result record manage- } \\
\text { ment }\end{array}$ & \\
\hline & Establishment of Safety Education & \\
\hline & Training Execution & \\
\hline & Training Management & \\
\hline
\end{tabular}

\section{Criteria for determining safety system maturity level}

A criterion is required to assign the safety system maturity level to an enterprise. For each level, the safety system scores are calculated based on how many items in each level are satisfied. If the number of positive answers exceeds $60 \%$ of the total "Safety n" items, the "Safety n" are considered "satisfied" as expressed by Eqn. (1). In addition, if some of items are "cannot be answered" for some reasons, such as unknown information or the absence of a facility, those are excluded when scoring the safety system maturity level. If the answer is "partly satisfied", the corresponding score for the item is multiplied by a weight of 0.5 . Here, a borderline for the criterion of 60 was referenced from a previous study [20].

\footnotetext{
Safety $n$ score: $\quad$ (Number of satisfied items) +0.5 (Number of partly satisfied items) $\times 100 \geq 60$ (Total number of safety $n$ items)-(Number of items that cannot be answered $)$

For example, if an enterprise gives 70 and 3 positive answers from 90 and 17 items in "Safety I" and "Safety II", that means to a pass in "Safety I" and a fail in "Safety II" resulting in "Safety l" finally.

\section{Application of evaluation checklist by safety system maturity level}

The checklist was applied to nine enterprises, which are four large, three mid-sized, and two small-medium-sized enterprises. Details on the enterprises are summarized in Table 3. The nine enterprises chosen were either in smart factory operation or in preparation. By business type, these were two display manufacturers, one mobile phone manufacturer, one logistics enterprise, and two electronic component assembly enterprises. Notwithstanding small discrepancies in size and business type, the enterprises have several points in common: similar processes or equipment. 
Table 3: Information on enterprises considered in this study

\begin{tabular}{|c|c|c|c|}
\hline Name & Type of Enterprise & Size of Enterprise & Main Facilities \\
\hline S1 & Display manufacturing & Large & Industrial robot, conveyer \\
\hline S2 & Cellular phone manufacturing & Large & $\begin{array}{c}\text { Industrial robot, conveyer, AGV, coopera- } \\
\text { tive robot }\end{array}$ \\
\hline S3 & Manufacture of auto parts & Small & $\begin{array}{c}\text { Injection molding machine, annealing ma- } \\
\text { chine, vibration melting machine }\end{array}$ \\
\hline S4 & PCB manufacturing & Small & Conveyer \\
\hline S5 & $\begin{array}{c}\text { Manufacture of automated device } \\
\text { protection }\end{array}$ & Small & Screen printer, chipmountor, reflow \\
\hline L1 & Display manufacturing & Large & Industrial robot, conveyer, AGV \\
\hline L2 & Logistics (loading) & Large & Conveyer \\
\hline D1 & Electronic component assembly & Medium & Industrial robot, conveyer, AGV, \\
\hline D2 & Electronic component assembly & Medium & Cooperative robot conveyer, AGV \\
\hline
\end{tabular}

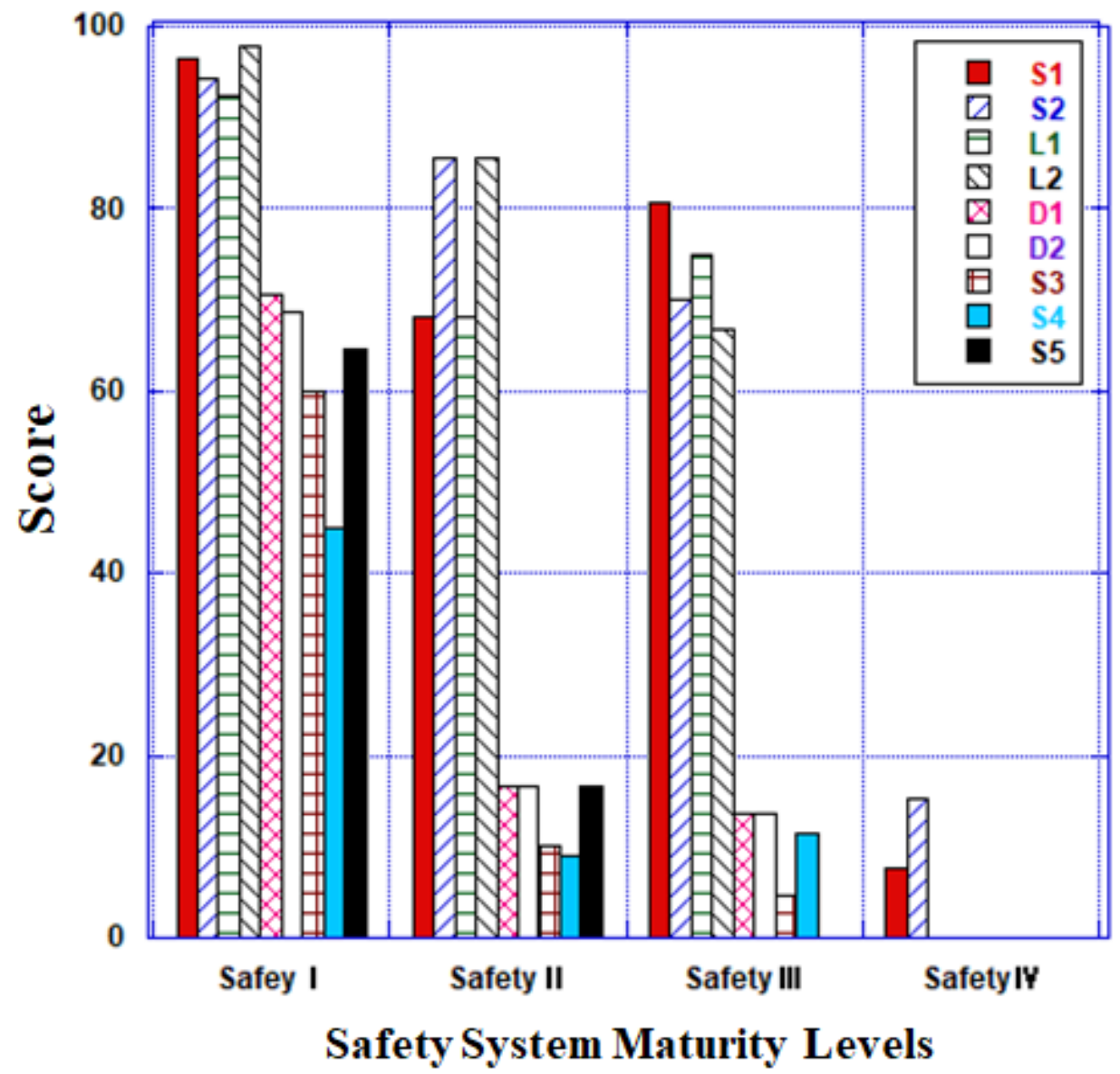

Figure 1: Safety system maturity level by workplace

Most of the items could be answered by research staff, however, some items required person-to-person interviews. For the items on devices and processes, some of all machinery and process were sampled and used to evaluate the safety system maturity level.

\section{RESULTS AND DISCUSSION}

\section{Analysis of safety system maturity by sized of enterprise}

The safety system maturity assessment results for the nine enterprises are shown in Figure 1.

Large enterprises (S1, S2, L1, L2) in this study passed the conditions of Safety I to III. The four enterprises have scores greater than 90 for "Safety I", and the Safety II 
scores of S2 and L2 are 15\% greater than those of L1 and $\mathrm{S} 1$. The difference is because some safety circuits at $\mathrm{S} 1$ and $\mathrm{L} 1$ could not be checked and the job processes were not fully monitored. In addition, there was no separate safety network, which is related to a safety system including emergency stop function. To ensure the emergency stop function, redundant wiring or sensors are required. However, as complicated wiring for redundancy can cause a communication problem of emergency shutdown malfunctions, separate safety network should be equipped to prevent the problem [22]. In Safety III conditions, S1 received the highest score of 81 . The superiority of $\mathrm{S} 1$ to the other large enterprises is found from data management. For example, S1 records and monitors the open-close histories of safety doors as well as persons entering and leaving dangerous zones. None of the enterprises have passed the condition of Safety IV yet, although, S1 and S2 seem to have Safety IV safety system maturity capabilities more than the other large enterprises.

All the medium-sized enterprises passed the Safety I. However, "Safety n score" in Safety I was approximately $20 \%$ lower than those of the large enterprises. The reasons are as follows; 1 ) it is not clear whether safety function-related circuits are configured, 2) safety certification components are not used, and 3) safety documents related to machines are not maintained. Moreover, all the medium-sized ones could not satisfy Safety II and III. Compared to the large enterprises, their deficiencies in Safety II and Safety III are: 1) safety function operation monitored, 2) safety system access management, 3) safety data collected and utilized. Monitoring functions enable to detect abnormal signals from equipment/instruments and control via remote monitoring functions. Thus, these functions are important because it can prevent accidents in advance and enable more desirable safety management activities.

Among the three small enterprises, S3 and S5 satisfied Safety I conditions, but S4 did not. The low Safety I score of S4 is due to insufficient safeguards and a paucity of safety documentation at some facilities. Undoubtedly, any enterprises other than large enterprises could not reach this borderline of Safety II and Safety III. This result is attributed to limited ICT infrastructure facilities, more specifically, for safety functions (e.g., using a computerization system, limited monitoring). Since a majority of small businesses are in the beginning stage of ICT, that led to low safety system maturity level on the businesses.

\section{Comparison levels of smart factory and safety system maturity}

Figure 2 shows a comparison between the levels of smart factory and the safety system of the enterprises. The abscissa and ordinate represent the safety system maturity level and the smart factory level, respectively. It can be easily understood that the level of the safety system maturity of one enterprise is proportional to the corresponding smart factory level, however, the former appears somewhat less than the latter. It can be reasoned that safety systems are not considered as important as productivity.

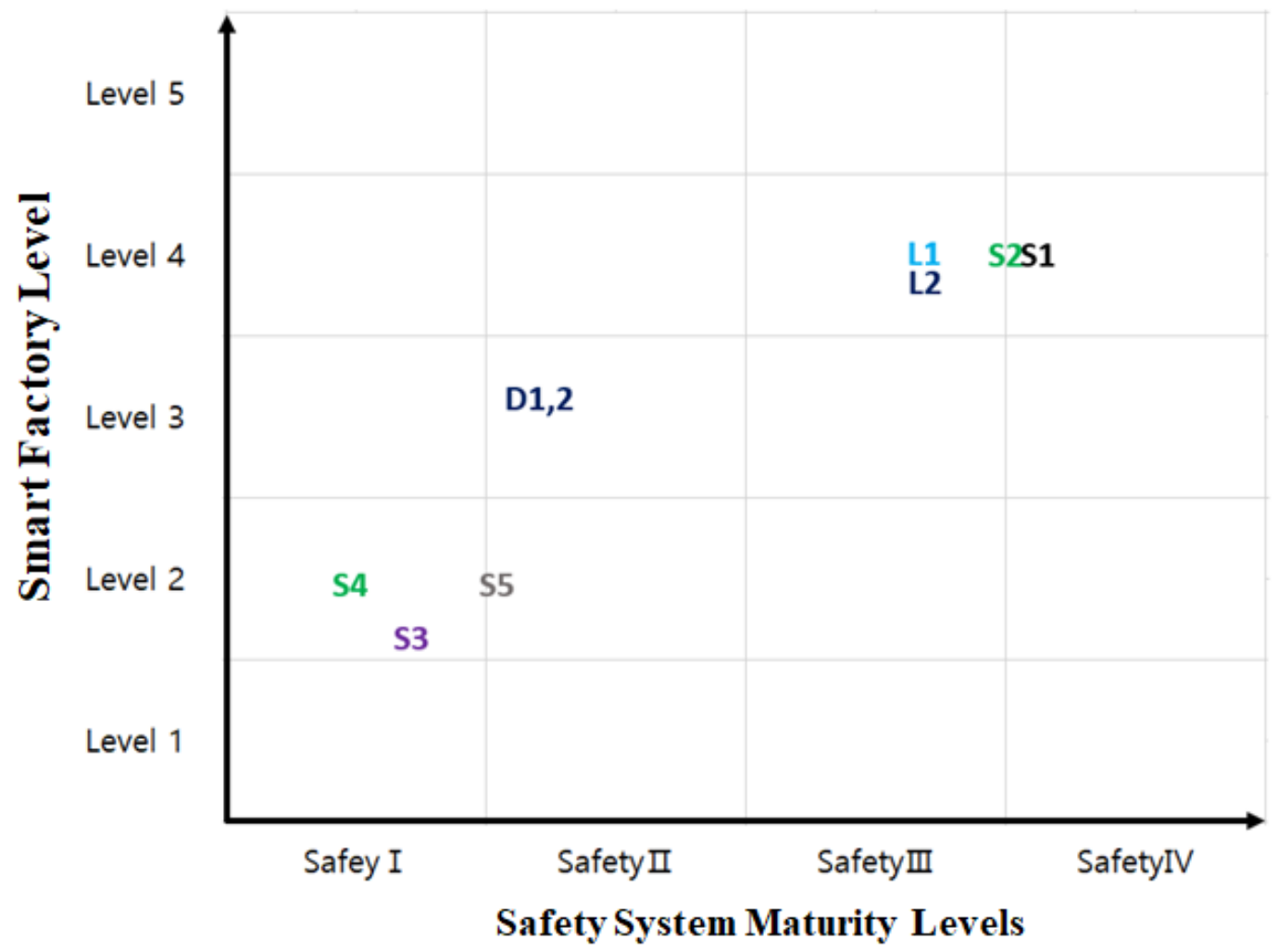

Figure 2: Comparison of levels between smart factory and safety system maturity 
Large enterprises were positioned at level 4 in terms of smart factory and at Safety III in terms of safety systems. Small and medium enterprises were at basic levels (levels 1 and 2) in terms of smart factory, and their safety system maturity level was Safety I or less.

\section{CONCLUSION AND RECOMMENDATIONS}

Motivated by insufficient safety aspects in previously developed "smart factory level verification system (SFLVS)", this study confirmed the safety system maturity in South Korea's smart factories through a checklist. The checklist is made up of 142 items so as to evaluate key devices safety requirements as well as safety management in a smart factory. After constructing the checklist, it was applied to nine domestic businesses via staff interviews. This is the first attempt to compare smart factory levels with safety system levels for Korean electronic manufacturing enterprises, this showed that both are related to the enterprise size. From the result, it is revealed that the larger size and more advanced smart factory level, the higher safety system maturity level. This relation comes from ICT utilization, which is fundamental to both the smart factory level and safety system maturity. However, ICT utilization of safety systems is lower than the company's technology level. This is believed to be because safety systems are not considered in evaluating smart factory maturity. In the introduction of high-tech technologies, it is necessary to consider safety systems together to reduce the use of technology and errors. Through the developed checklist along with SFLVS, what needs to be done can be identified for enhancing smart factory level and safety system level. In this study, the maturity of the safety system has been confirmed for a small number of South Korea's smart factories, and a follow-up study on how to establish an effective safety system in smart factories is needed.

\section{CONFLICTS OF INTEREST}

The authors declare that there are no conflicts of interest.

\section{ACKNOWLEDGMENT}

This study was supported by the Korea Occupational Safety and Health Agency.

\section{REFERENCES}

1. Rossmann M, Khadikar A, Le Franc P, Perea L, Schneider-Maul R, Buvat J, Ghosh A. (2017). Smart Factories: How can manufacturers realize the potential of digital industrial revolution. Capgemini. com. https://www.capgemini.com/wp-content/ uploads/2017/05/dti-smart-factories-full-report-rebranded-web-version_16032018.pdf (accessed on 2021-02-09).

2. Mičieta, B., Herčko, J., Botka, M., \& Zrnić, N. (2016). Concept of intelligent logistic for automotive industry. Journal of Applied Engineering Science, vol. 14, br. 2, str. 233-238. DOI:10.5937/jaes14-10907
3. Won, J. Y. and Park, M. J. (2020). Smart factory adoption in small and medium-sized enterprises: Empirical evidence of manufacturing industry in Korea. Technological Forecasting and Social Change, vol. 157,120117, DOI: https://doi.org/10.1016/j.techfore.2020.120117

4. Schumacher, A., Erol, S. and Sihn, W. (2016). A maturity model for assessing Industry 4.0 readiness and maturity of manufacturing enterprises. Procedia Cirp, vol. 52, 161-166, DOI: https://doi.org/10.1016/j. procir.2016.07.040

5. Karl L., Volker S., Roman B., Matthias B., Martin B., Agnes M., Katharina S., Edgar S., Moritz S. (2015). IMPULS - Industrie 4.0-Readiness. VDMA, Germany(Frankfurt):Impuls-Stiftung. https://industrie40. vdma.org/documents/4214230/26342484/Industrie_40_Readiness_Study_1529498007918.pdf (accessed on 2021-02-09).

6. Rockwell Automation, The Connected Enterprise Maturity Model, from https://literature.rockwellautomation.com/idc/groups/literature/documents/wp/ciewp002_-en-p.pdf (accessed on 2021-02-09).

7. Schuh, G., Anderl, R., Gausemeier, J., ten Hompel, M., Wahlster, W. (2017). Industrie 4.0 maturity index. Managing the digital transformation of companies. Munich: Herbert Utz. https://en.acatech. de/wp-content/uploads/sites/6/2020/04/aca_STU_ MatInd_2020_en_Web-1.pdf (accessed on 202102-09).

8. Lee, J., Jun S., Chang T.-W. and Park J. (2017). A smartness assessment framework for smart factories using analytic network process. Sustainability, vol. 9, no. 5, 1-15, DOI: https://doi.org/10.3390/ su9050794

9. Lee, J., Cameron, I. and Hassall, M. (2019). Improving process safety: What roles for Digitalization and Industry 4.0?. Process safety and environmental protection, vol. 132, 325-339, DOI: https://doi. org/10.1016/j.psep.2019.10.021

10. Dumitraşcu-Băldău, I. and Dumitraşcu, D. D. (2017). Occupational emerging risks affecting international virtual project Team Results. In MATEC Web of Conferences. EDP Sciences, vol. 121, 07003, DOI: https://doi.org/10.1051/matecconf/201712107003

11. Brocal, F., Sebastián, M. A., \& González, C. (2017) Theoretical framework for the new and emerging occupational risk modeling and its monitoring through technology lifecycle of industrial processes. Safety Science, vol. 99, 178-186, DOI: https://doi. org/10.1016/j.ssci.2016.10.016

12. Komadinić, V., \& Ilić, D. (2013). Risk assessment in small and medium-sized enterprises, specifics and differences in approach. Journal of applied engineering science, vol. 11, br. 3, str. 123-126. DOI:10.5937/ jaes11-3665 
13. Cho, J. H., \& Shin, W. S. (2019). Developing a Framework for Assessing Smart Factory Readiness of SMEs and Case Study. J Korean Soc Qual Manag, vol. 47, no. 1,1-15, DOI: https://doi.org/10.7469/ JKSQM.2019.47.1.1

14. Maasouman, M. A., \& Demirli, K. (2015). Assessment of Lean Maturity Level in Manufacturing Cells. IFAC-PapersOnLine, vol. 48, no. 3, 1876-1881, DOI: https://doi.org/10.1016/j.ifacol.2015.06.360

15. Tupa J, Simota J. and Steiner F. (2017). Aspects of risk management implementation for Industry 4.0. Procedia Manufacturing, vol. 11, no. 1, 223-1230, DOI: https://doi.org/10.1016/j.promfg.2017.07.248

16. Niesen, T., Houy, C., Fettke, P., \& Loos, P. (2016, January). Towards an integrative big data analysis framework for data-driven risk management in industry 4.0. In 2016 49th Hawaii International Conference on System Sciences (HICSS), 5065-5074, DOI: 10.1109/HICSS.2016.627

17. KMR CERTIFICATION, Smart Factory Level Verification System, from http://www.ikmr.co.kr/sub/ sub4_26.asp(accessed on 2021-02-09).

18. Mourtzis, D., Gargallis, A., \& Zogopoulos, V. (2019). Modelling of Customer Oriented Applications in Product Lifecycle using RAMI 4.0. Procedia Manufacturing, vol. 28, 31-36, DOI: https://doi.org/10.1016/j. promfg.2018.12.006
19. Jens Popper, Marius Blügel, Hagen Burchardt, Steffen Horn, Joachim Merx, Detlev Richter, Werner Varro, Michael Pfeifer, Pascal Staub-Lang. (2018). Safety an modularen Maschinen. Technology Initiative SmartFactory KL e.V., Report No.: Whitepaper SF-3.1. from https://www.phoenixcontact.com/assets/downloads_ed/global/web_dwl_specialist_essay/SF_WP_Safety_2018_EN.pdf (accessed on 2021-02-09).

20. Baek J. B., Lee K. B., Im J. G, Kim T. Y., Park J. M., Lim Y. M., Woo J. J., Joo O.G., Jeon S. Y., Shim J. H., Choi D. S., Yang S. B. (2018) Securing Safety of Smart Factory model development. Korea Occupational Safety and Health Agency, KOSHA. [in Korean]

21. Lee K. O. and Yeo H. O. (2017) Technical guidelines for safety concerning the use of industrial robots, etc. Korea Occupational Safety and Health Agency, KOSHA. Reprt No.: M-61-2017. from https://www. kosha.or.kr/kosha/info/searchTechnicalGuidelines. do (accessed on 2021-02-09).

22. Hiroo Kanamaru. and Taro Harima. (2008). Safety field network technology and its implementation. SICE Annual Conference, Tokyo, 1487-1490, DOI: 10.1109/SICE.2008.4654894. 